\title{
Export Performance and Stock Return: A Case of Fishery Firms Listing in Vietnam Stock Markets
}

\author{
Quy Thi VO' \\ Received: July 13, 2019 Revised: September 16, 2019 Accepted: September 24, 2019
}

\begin{abstract}
The research aims to study the relationship between export performance and stock return of Vietnamese fishery companies. To conduct this study, quarterly data was collected for period from 2010-2018 of 13 fishery companies listing in Ho Chi Minh Stock Exchange (HOSE) and Ha Noi Stock Exchange (HNX). The export performance was measured by export intensity, export growth and export market coverage. In addition, interest rate, exchange rate, GDP, firm size, profitability, and financial leverage were considered as the control variables in the research model. Panel data analysis with Generalized Least Squares model was employed to estimate the predictive regression. The findings indicated that export intensity and export growth have a significant and positive relationship with stock returns. However, export market coverage has not a significant relationship with stock return at the 0.05 level. Profitability, financial leverage, and exchange rate have a positive relationship, while interest rate and GDP have no relation to stock return at the 0.05 significance level. The findings imply that investors should consider the export intensity instead of export growth and export market coverage as selecting stock of fishery exports firms to invest; managers should increase export intensity to increase company's stock price or firm market value.
\end{abstract}

Keywords : Export Performance, Stock Returns, Fishery Industry, HOSE, HNX

JEL Classification Code : L25, G10, G30

\section{Introduction}

Many studies have been conducted on the determinants of stock return. Researchers have found that economic factors (e.g. GDP, interest rate, and inflation rate) and company factors (e.g. profitability, financial leverage, and dividend policy) have a significant impact on stock returns. However, a few studies on the influence of export performance of exporters on their stock return. VN-index increased sharply and reached 1170 points as Vietnam became the member of WTO in 2007 and responded positively as Vietnamese government signed the TransPacific Partnership (TPP) Agreement on 5, October 2015.

1 First Author and Corresponding Author, School of Business, International University VNU HCM, Vietnam. [Postal Address: Quarter 6, Linh Trung Ward, Thu Duc District, Ho Chi Minh City 700000, Vietnam] Email: vtquy@hcmiu.edu.vn

(c) Copyright: Korean Distribution Science Association (KODISA)

This is an Open Access article distributed under the terms of the Creative Commons Attribution Non-Commercial License (http://Creativecommons.org/licenses/by-nc/4.0/) which permits unrestricted noncommercial use, distribution, and reproduction in any medium, provided the original work is properly cited.
In the week from 30 September 2015 to 5 October 2015, VN-Index rose 24.5 points; the average trading volume of the market reached 208 million shares per day, a double increase of the average trading volume of previous weeks. Average trading value also increased twice, reaching 3,700 billion VND per day. The price of exporters' stocks increased dramatically such as TCM increasing $12.68 \%$, TNC increasing $17.15 \%, \mathrm{HCV}$ increasing $14.4 \%$, etc. In general, Vietnamese stock markets seem to respond positively as Vietnamese economy integrated with global economy. Therefore, this research attempted to study the relationship between export performance and exporters' stock returns in Vietnamese stock markets from 2010 to 2018 with case of fishery industry.

\section{Material and Methods}

\subsection{Export Performance and Stock Return}


Export oriented strategy also called "export led growth" was suggested by Ricardo and Smith in the 19th century based on the theory of comparative advantage of country. The theory supports the exchange of products/services between countries in international trade. Exporters gain competitive advantages through economic of scale, according to Giles and William (2000). Singapore, Hong Kong, Taiwan, and South Korea have achieved the fast growth by applied successfully export oriented strategy, and become the Asian Tigers (Todaro \& Smith, 2006). The followers are Malaysia, Thailand, Philippines, and Indonesia. Vietnam, Cambodia, and Myanmar are also trying to repeat the success of East and Southeast Asian countries.

Lal and Rajapatirana (1987) argued that exporting boosts company's sales and expand its markets to regional and worldwide beside the local markets leading to the improvement of company's performance. The reaching the economics of scale increases the company's profitability, in turns impacts positively on the company's stock price.

Export performance is the outcome of a firm's activities in export market (Zou, Taylor, \& Osland, 1998). It is categorized in two broad groups of measures: Financial/ economic and non-financial/non-economic measures presented in Table 1 below.

Table 1: Measurements of export performance

\begin{tabular}{|c|c|c|}
\hline Category & Authors (year) & Measures \\
\hline \multirow[t]{4}{*}{$\begin{array}{l}\text { Economic measures } \\
\text { - Sales- related indicators } \\
\text { - Profit-related indicators } \\
\text { - Market-share related indicators }\end{array}$} & Bilkey (1982) & $\begin{array}{l}\text { - Export profitability } \\
\text { - Export profitability growth } \\
\text { - Export profit margin } \\
\text { - Export profit ratio }\end{array}$ \\
\hline & Archarungroj and Hoshino (1998) & $\begin{array}{l}\text { - Export market share } \\
\text { - Export market coverage } \\
\text { - Export market share growth } \\
\text { - Profitability rate of export }\end{array}$ \\
\hline & Hosseini and Mirijahanmard (2011) & $\begin{array}{l}\text { - Export sales growth } \\
\text { - Export profitability } \\
\text { - Export intensity }\end{array}$ \\
\hline & Sousa (2004) & $\begin{array}{l}\text { - Profitability of export } \\
\text { - Growth in export sales }\end{array}$ \\
\hline Non-economic measures & Sousa and Bradley (2008) & $\begin{array}{l}\text { - Meeting expectation } \\
\text { - How competitors rate firm's export performance }\end{array}$ \\
\hline
\end{tabular}

Even though many variables used as measures of export performance, some of them seem to be used considerably more than others. Of which, sales-related measures were most often used to assess export performance, examined by two in every three studies (Katsikeas, Leonidou, \& Morgan, 2000). This study, therefore, inherits previous research by using sales-related and market-share related in economic measures as export intensity, export sales growth and export market coverage to measure export performance at firmlevel.

Maurel (2008) showed that companies with higher export performance have higher profitability. Bernard and Jensen (1999) found that exporters have a better financial wealth than non-exporters. However, the findings of studies on relationship between export performances and stock return did not bring about the same results. Bakhtiari (2001) did not find a significant relationship between export earnings and stock price in food firms listed in Tehran Stock Exchange. However, Yodollah (2013) indicated a significant relationship between export revenues and stock return on chemical firms in the same stock market.

\subsection{Vietnam Fishery Industry Overview}

With a coastline of $3.260 \mathrm{~km}$ and favorable natural condition for the development of aquaculture and fishing industry, the fishery has been contributed an important part in the development of Vietnamese economy. Vietnam has been the five largest seafood exporters in the world together with Indonesia and Thailand, and the third in fishery aquaculture and production, after India and China. The export turnover of Vietnamese seafood products has increased steadily from 2000-2018. However, from 2012 to 2015 , the export value reduced significant because of the reducing demand of some major markets such as Japan and 
EU. Then, it has recovered in the following years sharply. According to preliminary statistics of the General Department of Customs in 2017, Vietnamese enterprises have exported more than $\$ 8.3$ billion of various aquatic products, up to $18 \%$ compared to the performance in 2016. As a result, seafood is the 6th largest sector of Vietnamese export products in 2017. More interestingly, by 2018, the total value of fishery products reached nearly VND 228 billion, up to $7.7 \%$ compared to 2017; export turnover set a record level of $\$ 9$ billion, increasing of $8.4 \%$ over the previous year.

The selected firms as the sample of this study includes 13 fishery firms due to their available data, listed in HOSE and HNX before 2010. They are the leading exporters of Vietnam fishery industry. Their products are exporting to the United States, European countries, Japan, and South Korea. And now they have expanded their foreign markets to Middle East countries, African countries. The overview of their export performance from 2010 to 2018 was summarized in Table 2 below.

Table 2: Export performance of selected firms from 2010 to 2018

\begin{tabular}{|c|c|c|c|}
\hline Year & $\begin{array}{l}\text { Average Export } \\
\text { Intensity }\end{array}$ & $\begin{array}{l}\text { Average Export } \\
\text { Growth }\end{array}$ & $\begin{array}{l}\text { Average Export } \\
\text { Market } \\
\text { Coverage }\end{array}$ \\
\hline 2010 & 0.756 & 0.21 & 18.15 \\
\hline 2011 & 0.736 & 0.07 & 16.35 \\
\hline 2012 & 0.738 & 0.06 & 16.58 \\
\hline 2013 & 0.738 & 0.09 & 17.27 \\
\hline 2014 & 0.756 & 0.14 & 19.10 \\
\hline 2015 & 0.699 & $(0.07)$ & 19.12 \\
\hline 2016 & 0.524 & 0.22 & 17.67 \\
\hline 2017 & 0.527 & 0.05 & 15.50 \\
\hline 2018 & 0.499 & 18.46 & 14.00 \\
\hline
\end{tabular}

\subsection{Methodology}

To test the relationship between export performance and stock return, the research framework below was proposed.

\subsubsection{Variables and Measurement}

Dependent variable: Stock return $(\mathrm{St})$ is calculated quarterly by the formula: $\mathrm{St}=(\mathrm{P} 1-\mathrm{P} 0) / \mathrm{P} 0$, where: $\mathrm{P} 1$ : average adjusted closing stock price of quarter $\mathrm{t}$; and $\mathrm{P} 0$ : average adjusted closing stock price of quarter $\mathrm{t}-1$.

Independent and control variables are:

- Export intensity $(E I)=$ Total export revenue/ total sales

- Export growth $(\mathrm{EG})=($ Total export revenue quarter $\mathrm{t}-$ Total export revenue quarter (t-1))/Total export revenue quarter $(\mathrm{t}-1)$.

- Export market coverage (EM) measured by the number of countries which the firms is exporting their product to or export market coverage $=$ total number of company's foreign markets.

Control variables:

- Profitability $(P R)=$ Earnings after tax/ total asset
- Firm size $($ SIZE $)=$ Ln $($ Total asset $)$

- Leverage $(\mathrm{DE})=$ Total debt/ Total asset.

- Interest rate (IR) was collected from the website of Vietnam Commercial Bank (VCB).

- Exchange rate $(\mathrm{EX})$ used is direct exchange rate (USD/VND), and collected from the website of Vietnam Commercial Bank (VCB).

- Gross domestic product (GDP) growth rate is nominal GDP collected from Thomson Reuters page, GDP $=\mathrm{Ln}$ (GPD)

- Market conditions (MC) is a dummy variable, used to capture the market conditions from 2010 to 2013 (with the value of 0 ), and from 2014 to 2018 (with the value of 1).

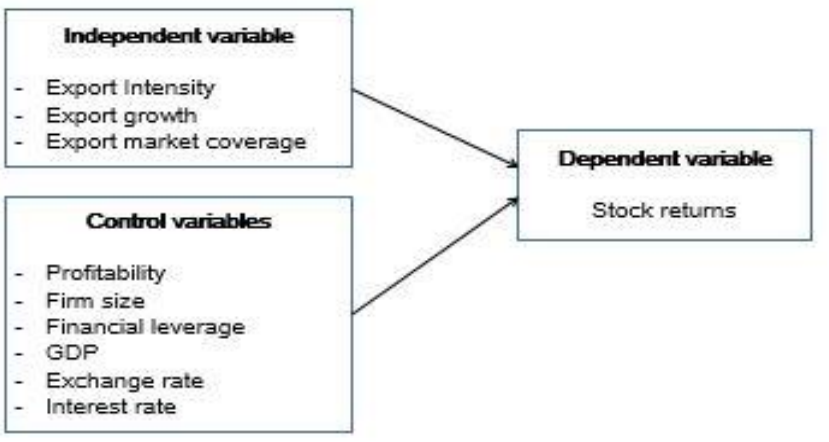

Figure 1: Research Framework

\subsubsection{Model Specification}

$\mathrm{St}=\beta_{1}+\beta_{2} \mathrm{EI}+\beta_{3} \mathrm{EG}+\beta_{4} \mathrm{EM}+\beta_{5} \mathrm{PR}+\beta_{6} \mathrm{SIZE}+\beta_{7} \mathrm{DE}$

$+\beta_{8} \mathrm{GDP}+\beta_{9} \mathrm{EX}+\beta_{10} \mathrm{IR}+\beta_{11} \mathrm{MC}+\varepsilon$

Where:

St: Stock returns

EI: Export intensity

EG: Export growth

EM: Export market coverage

PR: Profitability

SIZE: Firm size

DE: Financial leverage

GDP: Ln (GDP)

EX: Exchange rate

IR: Interest rate

MC: Market conditions

\subsubsection{Hypotheses}

H1: Export intensity has a significant positive relationship with stock returns.

H2: Export growth has a significant positive relationship with stock return.

H3: Export market coverage has a significant positive relationship with stock returns.

H4: Profitability has a significant positive relationship with stock returns 
H5: Firm size has a significant negative relationship with stock returns.

H6: Financial leverage has a significant negative relationship with stock returns.

H7: GDP has a significant positive relationship with stock returns.

H8: Exchange rate has a significant positive relationship with stock returns

H9: Interest rate has a significant negative relationship with stock returns

\subsubsection{Data Collection}

There are only 13 fishery firms listed in HOSE or HNX and have already published data from 2010. Financial data was collected from these firms' financial reports from 2010 to 2018 with total observation of 459 quarterly data points; GDP collected from Thomson Reuters; Interest rate and exchange rate collected from Vietcombank website. Stock price was collected from http://finance.vietstock.vn. Export revenue and export market of selected firms were collected from the report of Ministry of Industry and Trade.

\subsubsection{Statistical Description}

Descriptive statistics (Table 3) indicate that the average stock returns $(\mathrm{St})$ of fishery firms are in the range from $74.68 \%$ to $142 \%$ with standard deviation (Std.Dev) of $19.63 \%$.

Table 3: Descriptive statistics

\begin{tabular}{|l|l|l|l|l|l|}
\hline Variable & \multicolumn{1}{|c|}{ Obs } & \multicolumn{1}{|c|}{ Mean } & \multicolumn{1}{|c|}{ Std. Dev. } & \multicolumn{1}{c|}{ Min } & \multicolumn{1}{c|}{ Max } \\
\hline St & 468 & 0.002251 & 0.196297 & -0.74683 & 1.416425 \\
\hline El & 460 & 0.666144 & 0.259715 & 0 & 0.99558 \\
\hline EG & 463 & 2.158469 & 44.11131 & -1 & 949.1806 \\
\hline EM & 468 & 17.0812 & 11.8765 & 0 & 55 \\
\hline PR & 462 & 0.001025 & 0.213606 & -4.55734 & 0.119905 \\
\hline DE & 462 & 0.560556 & 1.031013 & 0 & 16.90234 \\
\hline SIZE & 462 & 17.01594 & 7.407445 & 10.83491 & 30.42986 \\
\hline IR & 468 & 0.073894 & 0.03506 & 0.0048 & 0.14 \\
\hline GDP & 468 & 1663332 & 937592.8 & 362895 & 4192862 \\
\hline EX & 468 & 21311.03 & 1027.778 & 18813 & 22825 \\
\hline MC & 468 & 0.555556 & 0.497436 & 0 & 1 \\
\hline
\end{tabular}

The average export intensity (EI) of selected fishery firms is $66.61 \%$ in the period from 2010 to 2018 . The highest export intensity is $99.56 \%$, the lowest is $0 \%$ (Q4/2015, ATA) and standard deviation is $25.97 \%$. It showed that export revenues contributed the large portion of the companies' revenues. The average export growth (EG) is $215 \%$, the highest export growth rate is $949 \%$, the lowest is $-100 \%$, and standard deviation is $44.11 \%$. With market coverage (EM), the average number of foreign markets that selected fishery firms exported to is 17 , the highest number is 55, the lowest is zero due to ATA had no export revenues in fourth quarter of 2015 as well as did not publish data in the following years (except 2016).

\section{Results and Discussion}

\subsection{Multicollinearity Test}

As two or more independent variables in multiple regression models are highly correlated, it would cause multicollinearity problem that generates ineffective regressors. The matrix of correlation analysis between individual variables is the easiest way to figure out the multicollinearity problem.

The matrix of the correlation coefficient (Table 4) shows that there is a high correlation between SIZE and EX; MC and macro variables as IR and EX. The magnitude correlation between other variables less than 0.7 ; therefore, it is likely to occur multicollinearity in the model. In order to avoid this problem, we rewrite the model (1) without SIZE and MC. The variable MC is already capture in EX and IR. For instance, when the market starts to recover, the interest rates will be decreased to boost up productions. At the same time, VND will also be devaluated to stimulate exports. Therefore, the final model is as below:

$\mathrm{St}=\beta_{1}+\beta_{2} \mathrm{EI}+\beta_{3} \mathrm{EG}+\beta_{4} \mathrm{EM}+\beta_{5} \mathrm{PR}+\beta_{6} \mathrm{DE}+\beta_{7} \mathrm{GDP}+$ $\beta_{8} \mathrm{EX}+\beta_{9} \mathrm{IR}+\varepsilon$

Table 4: Correlation Matrix

\begin{tabular}{|l|l|l|l|l|l|l|l|l|l|l|l|}
\hline & \multicolumn{1}{|c|}{ St } & \multicolumn{1}{c|}{ EI } & \multicolumn{1}{c|}{ EG } & EM & \multicolumn{1}{c|}{ PR } & DE & SIZE & IR & GDP & EX & MC \\
\hline St & 1 & & & & & & & & & \\
\hline EI & 0.0588 & 1 & & & & & & & & \\
\hline EG & 0.0458 & 0.0182 & 1 & & & & & & & \\
\hline EM & 0.0614 & 0.1529 & -0.0101 & 1 & & & & & & \\
\hline PR & 0.2053 & 0.1203 & -0.0243 & 0.1624 & 1 & & & & & \\
\hline DE & -0.0048 & -0.2987 & -0.0605 & -0.2159 & -0.1273 & 1 & & & & & \\
\hline SIZE & 0.042 & -0.4169 & 0.0588 & 0.0218 & -0.0427 & 0.2891 & 1 & & & \\
\hline IR & -0.0694 & 0.2907 & -0.0253 & -0.0131 & 0.1814 & -0.1883 & -0.702 & 1 & & & \\
\hline GDP & 0.0075 & 0.0609 & 0.0096 & 0.0624 & -0.0363 & -0.0592 & -0.2418 & -0.0563 & 1 & & \\
\hline EX & 0.1215 & -0.3185 & 0.0701 & -0.025 & -0.1266 & 0.2331 & 0.7081 & -0.6389 & 0.1717 & 1 \\
\hline MC & 0.0903 & -0.2634 & 0.042 & 0.0238 & -0.1344 & 0.2057 & 0.6264 & -0.8003 & 0.0879 & 0.7677 & 1 \\
\hline
\end{tabular}


We also conduct VIF test to verify the multicollinearity problem in the model (2). The coefficient VIF of all variables are less than 2 and the average of VIF is equal 1.28 or there is no multicollinearity phenomenon existing in regression model.

\subsection{Regression Results}

To test the research hypotheses, we run regression with the three models as Pooled OLS, FEM and REM. To test assumptions of Pooled OLS model, we performed heteroskedasticity testing through White's test and autocorrelation by Wooldridge test. White's test showed result that Prob $>$ chi $2=0.0000<0.05$, we reject $\mathrm{H} 0$ or there is the existence of the heteroskedasticity phenomenon in the model. The autocorrelation testing resulted in Prob > $\mathrm{F}=0.0192<0.05$, or $\mathrm{H} 0$ was rejected, i.e. there is an autocorrelation problem in the model (Table 5).

Moreover, Pooled OLS method may be suspected because of not considering unobserved heterogeneity or characteristics of each enterprise; therefore, the FEM and REM was used. Finally, choosing model was done through the Hausman and Breusch-Pagan tests, and the results showed in Table 6 and Table 7 below:

As a result, the most appropriate regression result is Pooled OLS model. However, Pooled OLS doesn't fix the heteroskedasticity and autocorrelation problems. Therefore, Generalized Least Squares (GLS) was chosen to explain the relationship between export performance and stock returns as the objective of this study. It was used as the results for analysis.

The findings showed four variables being exports intensity, export growth, profitability, financial leverage, and exchange rate have a significant impact on stock return at 0.05 levels. Especially, all of them have a positive relationship with stock returns. Three other variables being export market coverage, GDP and interest rate have a statistically insignificant relationship with stock returns at the $5 \%$ level.

Table 5: Summary of regression models and testing results

\begin{tabular}{|c|c|c|c|}
\hline Variables & Pooled OLS & FEM & REM \\
\hline $\mathrm{El}$ & $0.0707^{*}$ & 0.0758 & $0.0707^{*}$ \\
\hline$E G$ & 0.000172 & 0.0002 & 0.000172 \\
\hline \multirow[t]{2}{*}{ EM } & 0.000326 & -0.00154 & 0.000326 \\
\hline & {$[0.41]$} & {$[-0.84]$} & {$[0.41]$} \\
\hline PR & $2.360^{\star \star \star}$ & $2.603^{* * *}$ & $2.360^{\star \star \star}$ \\
\hline $\mathrm{DE}$ & {$[0.28]$} & {$[-0.76]$} & {$[0.28]$} \\
\hline \multirow[t]{2}{*}{ IR } & -0.194 & -0.27 & -0.194 \\
\hline & {$[-0.58]$} & {$[-0.78]$} & {$[-0.58]$} \\
\hline \multirow[t]{2}{*}{ GDP } & $-4.05 E-09$ & $-3.48 \mathrm{E}-09$ & $-4.05 E-09$ \\
\hline & {$[-0.42]$} & {$[-0.35]$} & {$[-0.42]$} \\
\hline EX & $0.0000295^{\star \star}$ & $0.0000304^{* *}$ & $0.0000295^{\star *}$ \\
\hline Wooldridge test & Prob $>F=0.0192$ & & \\
\hline Hausman test & Prob>chi2 $=0.5296$ & & \\
\hline Time fixed effects test & Prob $>F=0.8259$ & & \\
\hline Breusch - Pagan test & Prob $>$ Chi2 $=1.0000$ & & \\
\hline
\end{tabular}

Table 6: Testing results for choosing the model

\begin{tabular}{|l|l|l|l|}
\hline & Hausman & Time fixed effects & Breusch-Pagan \\
\hline H0 & $\begin{array}{l}\text { FEM and REM do not } \\
\text { differ substantially or } \\
\text { REM is more efficient } \\
\text { Than FEM }\end{array}$ & $\begin{array}{l}\text { All coefficient of } \\
\text { Model equal 0 or } \\
\text { Pooled OLS is more } \\
\text { Efficient than FEM }\end{array}$ & $\begin{array}{l}\text { Pooled OLS } \\
\text { Regression model is } \\
\text { More appropriate than } \\
\text { REM }\end{array}$ \\
\hline Result & Chi2 $(7)=4.14$ & F $(12,436)=0.62$ & Chi2 $(01)=0.00$ \\
\hline P-Value & Prob $>$ Chi2 $=0.5296$ & Prob $>$ F $=0.8259$ & Prob $>$ Chi2 =1.0000 \\
\hline Conclusion & REM is more & Pooled OLS is more & Pooled OLS is more \\
& appropriate & appropriate & \\
\hline
\end{tabular}


Table 7: Generalized Least Squares regression model

\begin{tabular}{|l|l|}
\hline Variables & GLS \\
\hline EI & $0.0979^{\star \star *}$ \\
\hline EG & {$[2.83]$} \\
\hline & $0.000180^{\star *}$ \\
\hline EM & {$[2.26]$} \\
\hline & 0.000917 \\
\hline PR & {$[1.13]$} \\
\hline & $1.721^{\star * *}$ \\
\hline DE & {$[4.27]$} \\
\hline & $0.0569^{\star *}$ \\
\hline IR & {$[2.00]$} \\
\hline GDP & 0.242 \\
\hline & {$[0.88]$} \\
\hline EX & $-5.20 \mathrm{E}-09$ \\
\hline & {$[-0.71]$} \\
\hline Cons & $0.0000400^{* \star *}$ \\
\hline & {$[4.25]$} \\
\hline
\end{tabular}

Significant: ${ }^{* *} p<0.05,{ }^{* \star *} p<0.01$

\section{Conclusions and Implication}

The main purpose of this study is to investigate the effect of export performance with measures namely, export intensity, export growth, export market coverage on stock returns of fishery industry and to determine the predictors of stock return. The study resulted in that export intensity and export growth have a significant relationship with stock return and showed positive effects. However, export market coverage has an insignificant relationship with stock return. This showed that the export intensity and export growth can be considered as an explanatory variable on stock return of fishery industry. Stock return will increase with increasing fishery firms' export intensity and growth.

The findings may be helpful for investors, firm managers and policy makers for their own purposes. Investors should consider the export intensity instead of export growth and export market coverage as buying stock of fishery exports firms. Manager should increase export intensity to attract more investors and increase their company's stock price. Besides that, policies makers should have suitable policies of interest rate and exchange rate to encourage and create favorable conditions for export activities.

The study has some limitations. The study just conduct on an industry with small sample is 13 companies in fishery industry in period from 2010-2018; therefore, the generality of the study's findings is limited. Further study should increase the sample size by extending to other exporting industries.

\section{References}

Archarungroj, P., \& Hoshino, Y. (1998). The impact of firm size on export performance and attitudes: An empirical study on Thailand exporter. Japanese Journal of Administrative Science, 12, 79-88.

Bernard, A. B., \& Jensen, J. B. (1999). Exceptional exporter performance: Cause, effect or both. Journal of Finance, $47(1), 1-25$.

Bakhtiari, F. (2001). Examining the relationship between the export earnings and stock prices in the food industry firms listed in Tehran Stock Exchange between 1373 and 1377. Tehran, Soroush, 2, 59.

Bilkey, W. J. (1982). Variables associated with export profitability. Journal of International Business Studies, 13(2), 39-55.

Giles, J., \& William, C. (2000). Export-led growth: A survey of the empirical literature and some non-causality results (Econometrics Working Paper No. 9901). Victoria, BC: University of Victoria.

Haghighi, M., Firouzian, M., \& Najafi, M. M. (2008). Identifying the determined factors of export performance in the food industry. Journal of Business Management, l(1), 3-20.

Hosseini, S. Y., \& Mirjahanmard, S. J. (2011). Companies export function: Identification of competitive advantage, implementing marketing tactics and export experience on export performance. Journal of New Marketing Research, $1,155-180$.

Ibeh, K. I. N., \& Wheeler, C. N. (2005). A resource-centred interpretation of export performance. International Entrepreneurship and Management Journal, 1, 539-556.

Katsikeas, C. S., Leonidou, L. C., \& Morgan, N. A. (2000). Firm-level export performance assessment: Review, evaluation, and development. Journal of the Academy of Marketing Science, 28(4), 493-511.

Lal, D., \& Rajapatirana, S. (1987). Foreign trade regimes and economic growth in developing countries. World Bank Research Observe, 2, 189-217.

Maurel, C. (2008). Financial approach to export performance in French Wine SMEs. Proceedings of 4th 
International Conference of the Academy of Wine Business Research.

Sousa, C. M. P. (2004). Export performance measurement: An evaluation of the empirical research in the literature. Academy of Marketing Science Review, 9, 1-22.

Sousa, C. M. P., \& Bradley, F. (2008). Antecedents of international pricing adaptation and export performance. Journal of World Business, 43, 307-320.

Todaro, M. P., \& Smith, S. C. (2006). Economic development. London, UK: Person-Addison Weasley. (pp.11-15).
Yodollah, K. (2013). The relationship between export performance, average stock returns of the exporting firms and the average stock returns of non-exporting firms in different industries in Tehran stock exchange between 1373 and 1381. Journal of Basic and Applied Scientific Research, 3(8), 45-48.

Zou, S., Taylor, C. R., \& Osland, G. E. (1998). The EXPERF scale: A cross - national generalized export performance measures. Journal of International Marketing, 6(3), 37-58. 